\title{
Public Universities in Post-Socialist States Could Become 'Un-Academic' after 2020 Pandemic
}

Andraž Teršek, Faculty of Education and Faculty of Humanities, University of Primorska and European Faculty of Law, New University

\section{Introduction ${ }^{1}$}

wo years ago (see Teršek, 2018), I publicly raised questions about
the "death of the university and the thoughtless professorships"
and the criteria for progress beyond mere technical development. Are professors largely career self-promoters and paper-repeaters? Are students prisoners of thoughtlessness and bureaucracy? Further, has science chiefly become 'manipulation'? Have reading and in-depth study been set aside somewhere in the area of eccentricity? Are books mainly modern 'boasting', not a way of talking to oneself and with others, who offer wit, knowledge and wisdom in books? Is this the world we are living in, has our world become like this?

In this article, I present major problems universities have faced over the last two decades, especially in post-socialist countries. This includes the Republic of Slovenia, a (post-socialist) EU member state. I present the legal, constitutional, social and bureaucratic aspects of the problem. The following issues are stressed: the lack of civil courage among members of academia (professors and researchers) to be more active and critical in public, above all at the expense of the deficient and sometimes unconstitutional legal policies of the universities. I outline the actual situation at universities and highlight the technical, financial and logistical problems faced by professors and researchers, some of which are quite paradoxical. I do so against the background of my own ethical understanding of my

I The starting points for this article are the previously published articles Teršek and Žgur (2010); Teršek (2017). 
role of a professor and publicly active critical intellectual, also a Slovenian "public watch-dog".

Emphasis is placed on the urgent, imperative (pressing) social need to raise the awareness of all those working in the university environment of their own responsibility for ensuring a high-quality education system, for protecting and developing knowledge as a value and for a democratic society based on knowledge as an absolute priority. I argue that high-quality knowledge is a prerequisite and the only means for assuring social progress. I mean this literally, emphasising the distinction between cultural progress and technical development. Universities should take more care here, not mostly focusing on technical progress or the market value of services and products, of the results of their educational and research work.

In writing this article, I relied on available scientific, professional and newspaper sources. At the same time, I wish like to emphasise that Io years ago discussions on this topic were quite active, frequent and, in part, passionate and controversial. Yet, over the last decade they seem to be less frequent and more restrained. On one hand, this is one of the big problems of today's universities while, on the other, it is an outcome of the backward, excessively bureaucratic and legalistic policy of the state when it comes to the organisation and content of work in universities. The excessive formalisation and bureaucratisation of legal policy in relation to the science, teaching and operation of universities has led to a situation which I critically assess as being the decline of the academic function and value of universities, their democratising function and their general social function.

With an obvious and devastating side-effect: that one can find ever fewer educated people (because having a university degree does not mean being educated), that students are less and less interested in real, accurate and thorough studies, that professors are ever less concerned with finding proper ways and means to motivate students to study and strive for quality knowledge, such that the younger generations find it ever more difficult to resist their lack of will, inspiration and nihilism (see Galimberti, 2010). This is especially the case when they realise that a university degree and high-quality knowledge do not guarantee them employment or employability as such. Finally, the creation of a family life, without also worrying too much about whether they will be able to provide themselves and their family members with a socially dignified life. ${ }^{3}$

2 According to the ECtHR (European Court of Human Rights) decision in the case Magyar Helsinki Bizottsag v. Hungary (2016). 
Before I bring this article to a close, I quote a conversation about universities, faculties, study, knowledge and the academic community with an eminent Slovenian philosopher, publicist, critical intellectual, professor and friend. I recorded our conversation (Teršek 2018) and translated it especially for publication in this article. I conclude by emphasising the obvious problem: knowledge as a value is melting and disappearing at the same time as universities are becoming almost non-academic institutions, if not "companies" (comp. Clark, 1998; Teixeira et al., 2004). ${ }^{4}$

\section{The lack of "civic courage"}

For far too long, the public, the media and people born during the socialist era have been asking why there are no more active, committed and critical citizens in the public sphere..$^{5}$ They wonder why one cannot find more young people who are more explicit and confident about issues that are not only interesting and serious, but also culturally and civilisationally decisive, perhaps even existentially significant. And why are there so few "velvet revolutionaries" left? What is the real reason for the absence of a massive and determined reaction to developments in society that is producing this situation of (e.g. Aristotelian) massive non-thinking and anti-politics, they ask? And why are so few academics-as-intellectuals willing to object and contravene the existing and dominating corporative organisation of society as a whole, being created - not by politicians and statesmen - but by daily political administrators - not rulers, but managers - who make up today's nobility? Why did people settle so quickly on a formal democracy instead of seeking and demanding a real substantial democracy? These questions and concerns are legitimate and justified. ${ }^{6}$

Education policy and the way universities work have much to do with the problem. Despite potential discomfort due to their modest effectiveness, academics must nevertheless make strong efforts to ensure their

4 However, in this article, I do not specifically address the issue of the relationship between the university and the market. By "production", I primarily mean a critical thesis about the functioning of public universities as the production processes of graduates and formal diplomas. So, I am thinking mainly of those aspects of the academy problem that I highlight in section 7 .

5 "Civic courage" is meant as a term describing willingness, sense of responsibility, consciousness, ethical self-understanding and courage for being and acting as an active and critical citizen, as a 'political animal' (according to Aristotle), to use intelligence, ratio and knowledge in public (according to Kant), to act as such publicly, addressing the state powers, members of the academia and general public as a whole, to be actively involved in public life, to publicly appear and act as an active and critical political subject, to be an intellectual (according to Sartre) as The Citizen (see Sruk (1986, 1995); Teršek (2008)).

6 For a comprehensive insight and overview of how the university in Slovenia was established, see Benedetič (1999). 
own participation in the discursive search and reflexive self-questioning about life, society, community, institutions, culture, national identity and the life situation - of every individual. Academics should pay special attention to questions concerning the role and status of knowledge in universities and educational processes in general. They must possess the desire to pay critical attention to the 'problem' of the university environment. Many representatives of scientific sovereignty and academic dignity in Slovenia have done so; convincingly so, yet still not enough of them. This means there can be no organised and joint action and commitment to progress (not to technical development). The lack of academics' moral courage (Haidt, 2013) is obvious.

\section{Unrealised political promises and harmful measures}

In the Republic of Slovenia, the university and the principle of university autonomy are constitutional categories. They are directly described in Article 58 of the Constitution: "State universities and state faculties are autonomous. The manner of their financing is regulated by law". This autonomy derives from the freedom of science and art, which Article 59 of the Constitution states is also a constitutional category and a condition for university autonomy: "Freedom of scientific and artistic creation is guaranteed". The first Commentary on the Constitution complements this fundamental premise of the constitutional protection of university autonomy. It emphasises that the autonomy of universities is primarily a defence right. This means that universities are independent and that, without state interference, they decide on their organisation and operation. Such autonomy also contains elements of the right to a positive status, which positively obliges the state to provide, within the framework of an organisational-legal and institutional guarantee, the basic organisational frameworks for state universities to operate in (Šturm 2002, p. 586).

After every parliamentary election, government coalitions have loudly declared the need for a political legislative reform of the education system and universities. The social democratic parties did so emphatically - by way of a promise. Still, these promises have not been kept. The rhetoric of the ministers responsible for education and science continue to differ markedly from the rhetoric used by party leaders during pre-election campaigns.

Instead of the necessary progressive step forward in the last io years, a noticeable step backwards has been taken. This chiefly concerns the autonomy of the universities. ${ }^{7}$ In particular, their total subordination to the

7 Former president of the Republic of Slovenia, Prof. Dr. Danilo Türk, addressed this question I2 years ago (2008). Also see Svetlik (1996, p. I19). Svetlik emphasises, among other 
rules and criteria adopted by state bodies and commissions which show disregard for the social role and professional value of teachers and professors (e.g. in terms of policy on salaries, rewards, employment and promotion), the financing of educational institutions, the systematic legal regulation of the basic segments of higher education (e.g. admission criteria) and the consistent implementation of the constitutionally correct legal regulation of the financing and operation of universities: ${ }^{8}$ with statutes, not by implementing provisions in implementing regulations. The state continues to represent its higher education policy with the slogan of necessary austerity measures, albeit extremely unconvincingly (Teršek and Žgur, 20IO).’

\section{Political technocracy and academic passivity}

Most characteristics of the Slovenian university environment are an obvious, direct and forced result of the state's legal policy, or better, an inappropriate policy. State authorities obviously and strongly intervene in the constitutionally guaranteed autonomy of universities (Komljenovič, 20I I, pp. 18-19; Komljenovič, 20Ira); from teachers' salaries through to the conditions for the state recognition of the legal validity of university diplomas and their funding. The constitutional unacceptability of this situation is clear. Also from the point of view of certain state requirements regarding the criteria to be met if universities wish to establish, modify and implement their study programmes. Even just the title of a particular study subject in a concrete study plan! $!^{\circ}$

University autonomy is also prevented by state bodies and commissions with regard to the content of university programmes. At the same time, these agencies and commissions (like the state administration generally) act in an excessively formalistic, technocratic, rigid and irritatingly bureaucratic way, including the criteria for selecting individuals for

things, that for the autonomy of the university it must first achieve a high level of internal integration (pp. I19, 122). For a brief overview of the legal acts that protect the autonomy of the university, see Avbelj (2019, 493, para. 3). Also see University Autonomy in Europe. Also explained in decision of the Constitutional Court of the Republic of Slovenia No. U-I-22/94.

9 For a detailed comparative analysis of the problem of the (non)autonomy of universities, see Estermann, Nokkala and Steinel (2011); Bennetot Pruvot and Estermann (2017).

Io The last personal administrative experience is nicely illustrated by the fact that my colleagues and I, working at one faculty at a public university, waited 6 years for formal approval by the state bureaucracy of the change of the title of the study subject. However, the problem of autonomy is not only a problem of European universities. See Polsky (2005), "calling for change, from small structural fixes aimed at dispelling faculty discontent to broad administrative alterations that will allow faculty to have more decision-making power". 
research and educational titles. ${ }^{.1}$ And the public universities show no real resistance (Močnik, 2011). They have uncritically adopted the system of unbearably formalised, intellectually uncritical and over-bureaucratic criteria, which are also not balanced among different scientific disciplines and have almost nothing to do with the actual substantive criteria for assessing the qualification of persons for research work and teaching. Public universities have easily accepted the aggressive neo-capitalist market logic whereby an individual should be entitled to recognition of benefit to the university or to a chair in a faculty or department of the faculty - not whether they are a sovereign expert in a certain scientific field and a good lecturer, but only - if "academic work can raise money - as a market product that can be easily sold to customers". ${ }^{12}$

The obvious reality seems striking: public universities do not want to be autonomous in any of these areas. ${ }^{13}$ It almost seems as if they do not feel responsible for autonomy. Or, even worse, as if they do not wish to take responsibility (Breznik, 20II).

The lack of responsibility may also be observed from an ethical and legal point of view: uncontrolled and unsanctioned cases of bullying and victimisation, plagiarism and other copyright violations, payment of remuneration for mentoring and commission memberships, spending public money on legal defence in cases of personal misconduct, cases of the obvious and serious loss of earnings, toleration of professors, those who do not consistently meet their educational obligations, the recruitment of students by allowing abbreviations in examinations and degrees, the establishment of programmes or even new faculties with the main aim of employing certain persons or closely related groups of persons, and not for the sake of compelling educational needs and purposes. The most diligent,

II Former constitutional judge and judge of the ECtHR Prof. Dr. Boštjan M. Zupančič in his dissenting opinions in Slovenian Constitutional Court decisions no. U-I-22/94 and U-I-34/94 similarly points to a reasonable understanding of the autonomy of universities. Also see Svetlik (1996, p. I20, fn. I). Like Zupančič, Svetlik stresses that the university cannot be absolutely' autonomous. He adds: "Too much autonomy can lead to the university's unresponsiveness to society, and too much responsibility can jeopardize its academic ethos and thus the essence of its existence". Such 'absoluteness' is not possible even with the fact that the state is constitutionally obliged to finance the university as a constitutional category. Of course, there is much room for manoeuvre between one extreme and the other, possible and unrealistic aspirations for absolute autonomy and the problem of insufficient autonomy. And this space is crucial. An ethical understanding of this space and its legal framework are vital. See Teršek and Žgur (20I0) and Lesjak (20II).

"We face enormous pressures of 'instrumentalization', turning the university into a means for someone else's end. These pressures come in two forms - commodification and regulation" (Burawoy, n.d.), comp. Teixeira et al. (2004). on Article 58 of the Slovenian Constitution in Avbelj (2019, pp. 492-500). 
receptive and constructive critical students are all too often overlooked and sometimes punished for demonstrating the critical and intellectual tension. ${ }^{14}$ And the problem of mobbing and harassment at universities remains without an effective answer. ${ }^{\text {Is }}$

Even if there are alternatives that universities could still use to choose appropriate ways to raise their level of quality and strengthen their role in society, these alternatives, these 'ways out' of total state control, typically remain unused. Within the framework of their unique function and privileged mission, universities must always share responsibility for the state of mind in society as well as for the general quality of social life. Also for a genuine democratic society in general. Such a philosophical and ethical self-image of universities seems almost forgotten.

\section{The value of work}

Domestic research work, public relations work and publications that are worth little more than nothing (publishing papers and books often means pro bono work, a way of collecting 'points' for one's habilitation and doctorate). Research work and publications abroad are worth everything, entailing a few paradoxes and a little hypocrisy when it comes to language.

Many professors are unable to give lectures to foreign students. They try to avoid them. Many of them simply do not want to speak any language other than Slovenian at the university. A professor does not need to be able to teach and write in a foreign language if they have the public funds to pay for translations of his scientific papers. These resources are not evenly distributed. Some have a lot, others have none. Consequently, a professor who can only write in Slovenian may have the most publications abroad and thus the highest score required for their habilitation.

I4 In late 2009, Radonjič published an article on the Crisis of Academic Consciousness: "The excuses offered by faculties to students, saying that the university is completely autonomous and therefore untouchable in its functioning, and therefore in violation of university laws, shows a lack of sense of what we call natural law, which includes the ethics of fundamental human rights and moral values. The autonomy of the university is not something absolute and must grow out of academic ethics".

Is See e.g. Judgment of the Administrative Court of the Republic of Slovenia No. IU 2178/2009-16, in which the court found that the reference to the autonomy of the university and the principle of secrecy of elections in habilitation proceedings is unjustified if a negative decision does not provide evidence and reasons for the final conclusion the candidate does not meet certain criteria for election, or if the decision is not reasoned in the light of the judicial assessment so it is possible to determine whether the deciding authority was guided by reasonable grounds while deciding in the area of discretion. Finally, the university is no stranger to classical mobbing, which is permanently present. This most important inhibitor of development, intellectual freedom, scientific autonomy and a desecrator of human dignity is not subject to almost any external scrutiny. 
If a professor is the editor of a high-ranking domestic scientific journal, they are able to decide who may publish in the journal, they publish their own work in the journal, and ensure that other authors publishing their work in the journal cite him or her in their work. Citations are an absolute necessity for habilitation, a doctorate and success in the competition for project funds, making it then more likely that such a professor will be specifically honoured. Or they will easily become the most influential member of the university commission that decides on the habilitation and promotion of their colleagues.

Last but not least, managing such a journal has become a lucrative business: peer reviews and the publication of scientific work come at a price: between 300 and 500 euros. Translations are expensive. And the translators prefer to translate the entire work rather than give lectures. The translation of a I5-page scientific paper costs from around 300 to 800 euros. At least seven publications in foreign journals with the highest rank are required to become a full-time professor. The salary of an assistant professor is about $\mathrm{I}, 800$ to 2,000 euros. It is therefore easy to take up mathematics (Faganel and Trnavčevič, 2016). However, to avoid misunderstandings, the professors do nothing wrong and there is nothing substantial to reproach them for. They are forced to do so in order to adapt to the system, to promote it and to survive within it. That is the systemic problem $!^{16}$

"Basically, this is a legal status issue. Only a short statutory provision that would guarantee state universities the legal status of a non-profit self-governing (autonomous) corporation would suffice the intention of the Constitution. The legal status of a non-profit corporation is, of course, not at all exotic, but it is quite common in Western democracies for universities (public and private). The source of the problem is neither primarily nor only in the Higher Education Act, but in the Institutions Act. With the Institutions Act, previously at least nominally self-governing institutions of both universities were essentially nationalized. It was only when this nationalization was carried out that the constitutional absurdity represented by the Higher Education Act could take place" (Zupančič, 1994; Svetlik, 1996, pp. 124-125), emphasises 25 years ago that due to the status of a public institution and the dominant public funding, the university passes from the direct influence of politics to the influence of the state administration. This problem, as explained in my essay, has deepened and grown worse in the last 25 years. It is unbearable, irrational, surreal and absurd. In 2016, the Higher Education Act (ZViS-K) formally transferred some competencies of the National Commission for Higher Education (NAKVIS; this is supposed to be a politically neutral and independent body acting autonomously and in line with the commitments of the Bologna Process, but practice has shown a different functioning) transferred to higher education institutions. The Council for Higher Education is supposed to perform only a consultative role, and higher education institutions are supposed to be autonomous, especially in the procedures for the accreditation and evaluation of study programmes. Again, practice shows a different picture. The fundamental, even the underlying problem not only remains, but in many respects even escalates: universities do not operate autonomously, even in those segments where they could or even should operate autonomously. The problem is similar to "media and journalistic self-censorship": public universities act as if they do not want to be autonomous. 


\section{Study programmes with ballast and deception}

A very important, yet almost overlooked, aspect of the public debate on university policy in Slovenia is the university's positioning within the framework of constitutional legislation. It has its roots in the recognisable and ethically questionable way in which (not only private, but also) public educational institutions pragmatically and profitably try to adapt to the legal framework and policies of the state, with the main goal of increasing the number of enrolled students. ${ }^{17}$ In accordance with the rigid mathematics of systemic rules and the paper-based logic of defining remuneration criteria, university professors are simply paid by the concrete number of teaching hours (measured in decimal numbers). These hours depend on the number of subjects they teach, with these hours in turn depending on the number of students: a system that can easily be manipulated. The professors most sought after by students can easily lose their subjects, their hours, their salary - and their position, their job.

Slovenia provides some examples of study programmes that appear to have been prepared surprisingly quickly, less precisely in terms of subject matter, not fully thought out in terms of personnel and logistically inadequate. In practice, certain study programmes do not follow the original and officially registered content, and the prognoses given by deans or study programme coordinators 'as a promise' or 'a legitimate expectation' regarding the students' employability sometimes amount to plain deception, lies and cheating.

Some of these study programmes were later exposed for the lies, manipulation, deception and fraud as concerns the value of their diplomas and employability. One case was taken to court. I asked students to file a lawsuit against the State which, while allowing the registration of the programme (invoking the constitutional doctrine of the positive obligations of the State) (Mowbray, 2004; Teršek, 2014, pp. 312-322), did not ensure the graduates' employability by including their official academic titles in the Official Gazette; no admission, no official professional title, no employability. Instead, they filed legal proceedings against the faculty! The court found no manipulation, no fraud and no deception. The students kept their diplomas (more or less as worthless paper) and became unemployed.

See Estermann and Nokkala (2009, pp. 18-26). The authors of the research find that in Slovenia there is in principle a system of integrated, 'one-block' funding of the university, but this is subject to extensive categorisation, which limits the financial independence of the university. They also note the trend of the (at least partial) conditionality of funding with financial formulas based on both 'input-related' criteria (e.g. number of students enrolled in the first year) and 'performance-based' criteria (e.g. number of new graduates). 
Such an educational policy of the state and the universities should be considered irresponsible. And unconstitutional. Lawyers should carefully examine the arguments about the legal contestability of such behaviour and the extremely harmful consequences for a growing number of young graduates. ${ }^{18} \mathrm{~A}$ society with such university policies and practices cannot claim to be a knowledge-based society. Instead, it is a society of the fateful intertwining of legal ignorance, political arbitrariness, economic brutality and ethical perversion (Bauman, 2016). It leaves young people in the grip of nihilism and a crisis of meaning, something that must be countered (Splichal, 2010).

The signs chosen by Slovenian public universities to achieve the goal of a progressive society and a knowledge-based value society are not optimistic. I maintain the public universities do not care enough about the development of critically thinking citizens, ethically aware people, moral personalities and civil, courageous intellectuals who are motivated and equipped with knowledge. Universities do not care enough about the development of self-confident young generations (a vast problem addressed by Galimberti (2010) that represents one, but the most important, outcome of this obvious fact). Universities still do not care enough about knowledge as a value, about morally sound and rationally persuasive education (Haidt, 2013) as something that is an end in itself in the educational process (as opposed to assessing the value of knowledge in relation to its mere value as measured by the market) (comp. Splichal, 2002; Burawoy, n.d.). Yet, this concern is far from being entirely dependent on the legal and political stance that any government coalition adopts towards universities. ${ }^{19}$

I8 My personal and professional conviction has always been that the mere pursuit of the cruelty of the 'letter of the law' is the most primitive form of the rule of law and the highest degree of obstruction of the rule of law. Even the fundamental questions about right and wrong, the acceptable and unacceptable, the permitted and prohibited must directly affect the most important values (we create these people more than we discover them), moral answers (initially intuitive, Haidt 2013, Part I) and ethical considerations (about decency, suitability and general utility), which are not originally conditioned by a system of authoritatively enacted formal rules and are functionally independent of the letter of the law. It must be exactly the opposite. The judicial system, public administration and structured systemic violence, which are exercised through the terror of dehumanised thoughtlessness, bureaucracy and paperwork, work in reverse. Instead of the rule of law, therefore, legalistic legalism and paper legalism (legal transcription) prevail (also in the courts). Instead of the ethics of right and wrong, there is a relativism of what is allowed: systemically protected actors are allowed to do anything that is not expressly forbidden, with the possibility of taking responsibility for the service of an expressly forbidden exception to the rule. Justice does not really exist. Constitutionalism is treated as a disruption to the system. Democracy is only formally eligible for election (Teršek, 2018a). See the Magna Charta Universitatum, which states that "the future of humanity depends 


\section{Discussion with a fellow professor about the 'state of affairs' regarding universities}

Two years ago, I had a discussion with Assoc. Prof. Dr. Tonči Kuzmanić, an eminent philosopher, publicist, critical intellectual and a person with enormous knowledge, also a friend: about universities, faculties, studies, knowledge, and the academic community. I wrote our conversation down (Teršek, 2018) and translated it for publication in this article. ${ }^{20}$

Tonci, do you agree that Prof. Umberto Galimberti is addressing exactly what is happening in Slovenia with this criticism, this warning and this concern (note: in the book Horrible Guest-Youth and Nibilism)? The lack of real content and thought, the complete usurpation of the academic university sphere by what Galimberti calls naked technical rationality? I mean... So, it is no longer about content, but only about the path to a simplified goal. This goal is simply the mere acquisition of some form, in the form of a diploma or something else. And this diploma does not really reflect anything substantial, it is not addressed to anyone directly, and it does not deliver anything substantial. It is only a result, the end product of a process in which it is made technically, rationally, administratively, bureaucratically, 'face to face' and on paper completely banal, to the point where a thesis is made, but not in the first

to a large extent on cultural, scientific and technical development and that it is built in centres of culture, knowledge and research centers, as represented by serious universities".

Assoc. Prof. Tonči Kuzmanić is one of the best educated members of the Slovenian academic community. In the period before Slovenian independence, he was one of those people who, with their knowledge, intellect and critical thinking, 'plowed the furrow' for Slovenia's liberation from the clutches of the former common state of Yugoslavia. He was co-founder of the central Slovenian journal for critical civic thinking, an initiator of numerous scientific projects and civic activities, which with determination, courage and sincere commitment to freedom, dignity, fundamental human rights and the political ethic paved the way to an independent state, of the Nation of Slovenia. He was an editor, columnist, author of numerous scientific articles and newspaper articles, author of several books, a university professor, head of scientific projects of international significance and a man who always held a critical mirror up to political power and (as he calls it) "political management". Together with other university colleagues, we designed a new course of study in "political science" at the University of Primorska in Koper (Slovenia), which unfortunately did not last longer than 5 years due to bureaucratic constraints based solely on the number of students enrolled. Kuzmanić has now retired. And he still writes and reads every day and most of the evening. Along with everything else, he is also my friend. And a teacher of sorts, not just a conversationalist. By publishing our conversation in English for this publication, I thank him in a way for his attention to my work and for the knowledge and wisdom he has shared with me over the years of our friendship. Especially on the subject of the university, the academic community and politics in a genuine, Aristotelian sense. At the moment, he is probably catching some fish early in the morning on the island of Vis in Croatia, reading a book and preparing dinner for his friends and acquaintances from that island. 
place: it is an incredibly technocratic, administrative and naked bureaucracy, which has become even worse at the level of the university sphere than at the level of state public administration. First, because the consequence of this is actually even worse in practice, because what can still be agreed behind an official desk when you meet a reasonable person is no longer possible in the university sphere. Because these reasonable people hardly exist. And, second, because we should not be able to afford this at all at the university level, without this happening to an even greater extent than at the state level. Do you share this concern?

As far as I am concerned, definitely. What I think is particularly, and noteworthily, the death of the university. In short, we assume that the university simply 'is'. We assume that the professors simply 'are'. And we assume that the students 'are' too. These are just empty forms and shells, just like the appearance of a student. The origin of a student is this: it's about being formally enrolled and having a formal status and that what you said happens formally - on paper. We know that this paper is no longer worth anything. We all know that today, and tomorrow, it will be even less valuable. The matter has gone so far in terms of content that today we have idyllic data from people who say that a pupil, a high school graduate, is writing a doctoral thesis at the university. There are no serious problems at professorial level. So far, we have only talked about this Galimberty setup, but I will go one step further. It is important to stress this: at the professorial level, we overlook the fact that we no longer have a professor - because he was forced to become a researcher. We no longer have a professor. Professors are rare. And just as our colleague Dr Primož Šterbenc does not even have a mobile phone, I do not have research and neither do you. Today, we have strategies of choice, these are questions of freedom and political decisions. ${ }^{21}$ Today, if someone wants to have money, wants to be at university, it is not enough to have only references, he must also have 'projects'. But if he has projects, he cannot be A Professor at the same time! If he is a professor, he teaches and because of this, not because of what he does on projects. What can you teach with regard to ultra-specialised things about your project to someone coming as a student into your first year? What would you expect in your first year? If he's a sociologist - the general categorical apparatus and basic discourse of the social sciences, a critique of it. If he's a philosopher - Greece. He, on the other hand, will come - I am talking on the level of philosophy - and talk about a degree course, not something that the Lacanians desired, but something

2I For $\gg$ voter-deciding process $«$ from the standpoint of morality and psychology, see Haidt (2013, pp. 97-119); Gilbert (2013). 
small, even though important and substantial. In the first year of study, what can a student expect?! Then you will have a graduate philosopher, and you will ask him what the truth is like with Aristotle, and he will say: I do not know. He had never even heard of Aristotle. But if you 'tune in' and ask him something about Lacan and Žižek, for that matter, he will say everything by heart. Žižek and Lacan are not philosophers. This has nothing to do with philosophy. It's at most something like a cultural patch after psychoanalysis, or psychoanalytic theorising about culture and possibly philosophy. But that is what we have.

\section{And the result is...?}

That we do not have a university. Death to the university. What is the sign of the death of the university? The sign of the death of the university is that when students fantasise about studying, they are actually not reading anything. Today's student body is not able to read a basic text, be it Spinoza or the already mentioned, I love Aristotle! Be it Marx or anyone. They are unable to read, or rather they are not so read. And why? Because the professors did not teach them to read correctly and truthfully. Just as the students see themselves as students, the professors see themselves as professors. In fact, they are researchers, craftsmen and earners. What is the result? What I call the death of the university. The problem is that when you say it today, it is understood, interpreted and explained in this way: oh, sorry, it is not entirely so, because your criticism is too harsh, it's not so bad, because you are exaggerating. No, that is exactly the point. It is about the question of whether we are prepared to look at the 'animal' we are dealing with, this 'human animal', which is called a 'social being'. This 'shoe'. This is what we are dealing with. It is no problem to say this in technical language and say that we are dealing with technology, with technical form and so on. The problem is that you have to bring it, as I have done now, to the level of concrete people. In other words, it is about my generation of professors, this story is about myself and about us. And about the student population.

\section{Well, it seems that nobody is really interested in it...}

Look at what we are talking about today, but I bet there are not five students who would stay here just to listen to this discussion. What does that say? What we are doing, what we are talking about today as a problem is not a problem of the student generation at all, because the student generation does not have a problem. And, all in all, it is about, it is not a problem for them, but for us who are already leaving. In this sense, the faculty, the university, the academy is dead. There is no other way out than 
opening a 'microphone'. With Plato and Platonisms there will be no way out, we will have to open ourselves against politics, against political action and against Aristotle. ${ }^{22}$ That will no longer be possible: culture is here and culture is there, and we are very cultural and we are very social. After all, these are examples of fundamentalisms, and they are predominant here, fundamentalisms of economic origin. Here the economic type of language and 'unplanned' gibberish prevails. But it is not easy to get out of here. The academy is completely immersed in economic fundamentalisms and in business types of chatter about the market, technology, efficiency, progress, productivity... These are also many myths from his thicker book (note: Galimberti’s book Myths of Our Time).

\section{Do we also talk about goals and purposes?}

Galimberti, since you introduced him before our discussion, and it was not a bad choice... He does not distinguish between goals and objectives. So, my combat strategy is a different one. As a professor, I have discovered something fascinating, deadly and devastating for me over the last 20 years, which I have already put into words here and elsewhere, so I will now only talk about how I approach it. My basic insight from my quarter century of work and work with students is that male and female students are illiterate. That they are actually illiterate. I did not say this by chance, and I know what I am talking about. I am speaking empirically, from work that has begun over the last 25 years with the student population. You already know how to read the series and what is written below. But if you give them a certain professional, scientific, philosophical, ethical, political text, they are illiterate. They cannot break through from sentence to sentence. This is a fundamental insight. In other words, if in the past, in my generation, in high school it was considered 'not good because they will read at the faculty', today we have children in faculties who are not lazy, without wanting to avoid misunderstandings. They are simply not capable. They are incapable of reading more demanding texts. And it is not just about foreigners. They cannot do this. I interpret this as a generation of images. But that is another story.

\section{How can you fight this or fight against it?}

Very simple: I teach them to read. What else should I do? When I am at the faculty, when I have a student population, when they cannot read, what else should I do? They might think as they heard it among listeners and giggles, as if I was joking and not doing it. No, that is exactly what I 
do. I even worked out a special programme, with the help of my colleagues, you included, who also took part in this reading tour, only a little harder to read: Aristotle, Marx, Heidegger, Hannah Arendt... they went through this torture. We have formed a team that teaches, at this point, let us say, we read the first supporting text of management theories. But beware, at university level, in the programme of every faculty, you will not find the opportunity to teach Scientific Management to someone like that. Many years ago, 20, 25 years ago, I taught at the Faculty of Social Sciences, to read the text 'The concept of the political of Carl Schmitt'. From end to end. But please take this seriously - there is no other way. However, just as the teachers pretend to know things, they are semi-skilled. The teachers of today are semi-educated intellectuals in the categories of 30 years ago. As a result, there is an even less educated, semi-educated student population who only imagines that they are students and that they understand.

\section{So, this is a time, an age that we would describe as...?}

We are living in an age of lies, imagination, images and deception. This is what we are dealing with. In short, the matter is infinitely more serious. Brutally more serious than it seems. From here, there is the need to be beautiful, to have your nails cut, from here it is very important whether it stinks in your armpit or not; that whether you read books does not count. That you understand does not count. The only thing that counts is the phenomenon. Just look at the commercials and you will see an enormous number of beautiful faces. These faces are semi-literate. These are very serious things. For us it's something new, for America it's something ordinary. It's something new here that we can look at as a problem. Not for America. In that sense, it seems infinitely more serious. I have not given up. Speeding at roo kilometres an hour, I am afraid. Unfortunately, simply by learning how to read.

And then we come to the point where natural scientists decide the academic fate of social scientists and humanists. However, only a convergent language and a binary decision-making process are used. Is there a problem? An interesting paradox?

That is right, but I do not have that feeling. It's very easy to settle the matter by saying that the natural scientists are to blame, leave us social scientists alone. I think the opposite. I am nominally a social scientist and a humanist but, if you ask me for my opinion, I must emphasise the question of who resigned. Let us say, in cases such as those that occurred in Slovenia about a quarter of a century ago. What is going on here is not something that happened here in the 1970s, it is not something 
that happened here in the 1980 s. I know that, I was living at that time. Whether I was a student, whether I was doing a master's, a PhD, or whether I was in the age scene, I wrote for the youth. I know that was not good then. It came with so-called independence, it was closely related to the processes of capitalisation, the processes of the 'managerial revolution', and two books have been written about it that you can read, and I will not go into them further here. The question of who resigned must be answered: the humanist and social science intelligentsia. The humanist and socialist intelligentsia are the ones, they are the ones, we are the ones and they are the ones who have resigned. It is not two million and several thousand Slovenians, it is a dozen, a few, hundreds of people in whom the next game was played. Some, namely the circles of the New Magazine, went the way they have just gone. And they are not problematic from the point of view of an argumentation that interests me and that I want to serve. Others, however, split into two parts, one of which advocated something like the managerial revolution, liberalism and so on, mostly economists and so on. The humanities, on the other hand, mostly started barking at the moon. You will not like what I am going to say now because I assume that you are predominantly left-wing. This moon is called Capital. And then we have this situation. The left - humanities and social sciences, barking at capitalists and capital, economists and managers privatise and rob everything that can be robbed. The more managers robbed, the more the left barked at capital. Nothing has changed, not even today. That is the main responsibility. Not the main responsibility of the right. Of course, you normally had to expect the right to make the moves it made. You cannot expect anything else from economists and managers than to tweet neo-liberal, neo-conservative arguments. From the left, I am now talking about the Faculty of Social Studies and the Faculty of Philosophy and some of the institutes that deal with it, it was necessary and necessary to expect them to choose and correctly understand the problem, the state of affairs. I remember the Peace Institute working at the Faculty of Social Sciences for a while. I am also one of the founders of the Institute. We held out until the NATO referendum, until the very end. At that NATO point, we had used up all the energy we had invested and were defeated, of course. We got $34 \%$ in the referendum, and that was the end. The Peace Institute was the 'last Mohican' that tried to defend the little things. Then came the wave of the Faculty of Social Sciences and the wave of the dumping Faculty of Philosophy - of capital. 
The practice of not thinking like, not so controversially, is that which is regarded as being reasonable and accommodative. Isn't this exactly how it should not be regarded?

Today, we find ourselves in a desert of thoughtlessness. In this sense, it is necessary and powerful to speak directly and without mercy. We are no longer living in times of deception. I do not want to offend Prof. Slavoj Žižek, but I also do not wish to offend Dr. Milan Brglez, and I do not want to offend Prof. Mladen Dolar.23 These are passing times. If you want to do something, to think, to act, especially politically, you have to take stock. I know that you did not expect this, but I did not come from the Slovenian seaside for nothing. Ljubljana is where it stinks. This is where decisions are made, this is hypocrisy, this is where the elite is responsible, this is where it happens. But here, those I am thinking of are sunbathing at the same time and they are stars and appear in the media and on television. But if you go on TV and start talking the way you should talk, then the show is banned. If you think that you are living in a democracy and that the matter is being published, that there is no such or other blockade, no more censorship, then you are wrong and you do not know where you are. In short, things are infinitely, infinitely more serious than you think. They are not bad at all, they are catastrophic! Really. Although I know you do not believe me.

You now I am not a disbeliever when you take firm stands and speak your criticism out loud. I do it all the time, so we don't have a problem here. But, anyway, is there still something, 'that thing' which could legitimately be called discourse in the public space?

This discourse does exist, but is very rare. Let us say that the people we are talking about here are mostly Heidegger, Hannah Arendt, Guenther Anders. Heidegger is present, but he is occupied by the Slovenian right and acts as the blackest point, the black sheep. In this sense, you cannot get it anywhere at the university. Hannah Arendt cannot come, so to speak, to the university, she does not fit in. These are the key arguments of the left scene here. There is no Guenther Anders. In short, it is a completely new paradigm, and in this sense I said at the beginning that it is bringing a new wind to Slovenia. It will no longer be an accusation against Lacan, an accusation against Marx, but something else. Freud is there, but not as an indictment of Freud, but as something new. What is new is not so much the speech about the book, but its interpretation. My professor, Andrej Kirn, for example, who has studied it. But who reads Prof. Kirn

23 See post scriptum at the end. 
anyway? Something small has been said among the people on the right side, between the philosophers Prof. Urbančič and Prof. Hribar, but even that is not something you can read. The problem is that it is not read at all in the so-called author scene. Who reads Hannah Arendt on the age stage? Who is able to read her book Vita Activa? These are other ways of speaking.

Or to go back to the beginning, to hear that too, because it is not serious. This is the way, one of the possible ways, away from Platonism, towards Aristotle. See information. Don't you find it strange that for half a century or 60 years there hasn't been a single doctorate on Aristotle? At the University of Ljubljana? Count how many there are on Freud and Lacan. Well, neither Freud nor Lacan are philosophers. How is it that the basic philosopher Aristotle has not been the subject of at least one doctorate at the Faculty of Philosophy in just over half a century? Something is seriously wrong, something is very seriously wrong. In short, there is a certain paradigm within which we move, there are certain closed horizons in which we find ourselves and walk through our own labyrinths. And then we discovered Capital, and now we are going to make a revolution against capital? For me, it is an infantilisation of the population. Infantilisation, I emphasise. The responsibility of the left for what is happening here is very serious. It is a very serious responsibility. And, instead of talking about responsibility, they, these... as celebrities... they can afford to sunbathe and are popular and dominate everything and people read their stuff, their bestsellers. That's not me. But I am not a problem. We are not the problem. The problem sticks with them. And is a serious one, overwhelming and devastating for the long term.

\section{End of conversation.}

At this point, it may be appropriate to provide further clarification. Five years ago, I was a member of a working group of professors who, on the initiative of Prof. Kuzmanić, established a new course of study in political science at the University of Primorska (Koper, Slovenia). After 5 years, the programme was discontinued. The reason was that the number of students (between 5 and 8) was too low, which made the cost of implementing the programme too high for the University. The University therefore gave up political science. I believe that no further comment is necessary. However, some young students were well educated in political science during these years. 


\section{A 'clear and present danger' of slipping into complete non-academicism}

The responsibility and accountability of the universities for enhancing formal democracy with truly democratic content is great and important. ${ }^{24}$ Without the necessary and constitutionally provided autonomy, the universities will be unable to exercise this responsibility. Nor will they be able to exercise it without the firm commitment of all academics and administrators working in universities to operate in an ethically credible and legally sound manner (Freitag, 2010). ${ }^{25}$

Instead of resisting the purely bureaucratic and brutal administrative conditions and criteria for selecting and appointing teachers, professors and researchers, the universities have completely uncritically adopted this type of dictates imposed by state authorities and committees. Academics are not motivated enough to focus on the content and ethics of the work processes in public universities, but are forced to be increasingly passive and apathetic assistants (servants or slaves?) to the technocratic dehumanisation of the academic world and the unbearable bureaucracy. Universities have considerably failed to take care of the education of critically thinking citizens, of moral personalities, civilly encouraged intellectuals equipped with authentic and quality knowledge. In view of what has been happening in public universities over the last Is years, it is almost impossible to speak of the obligation of universities to safeguard and increase knowledge as a value. ${ }^{26}$ It would appear that the universities have become almost 'un-academic' in such a post-socialist field (Marušič, 1997). ${ }^{27}$

24 "Accreditation systems, properly designed and mandated, can be powerful forces for quality and change in any complex system. This is particularly true of the institutions of medical education. Accreditation can support countries in their regulatory obligation to institutionalise quality assurance approaches and guide individual institutions in their development. Therefore, it is very important to pay close attention to developments in this area. There is an urgent need to foster the adaptation of accreditation standards and norms that reflect social accountability. Only then can educational institutions be measured and rewarded for their real capacity to meet the pressing health care needs of society" (Boelen and Woolard, 2009).

See Freitag (2010). Oh yes, how it shipwrecked.

26 See Polanec (2011): "One of the most important development issues is how to organize higher education in such a way that academic goals such as placing Shanghai University at the top roo in the world can be achieved, but also economic goals such as improving innovation and creativity in society, increasing the number of patents and accelerating economic growth. We have been waiting for well thought-out measures for more than twenty years, which means that the transition in higher education has not even begun. The reason for this situation is, as usual, a lack of understanding of economic incentives in education, a dogmatic view of the organization of higher education and a lack of will to deal with interest groups such as students and lecturers who, in the current situation, have high rents" (Translated by A.T.).

One again, particular mention should be made here of the judgment of the ECtHR in the case Magyar Helsinki Bizottsag vs. Hungary (2016), which recognises the status of "public 


\section{Closure}

I have been discussing and corresponding with my colleagues working at public universities in Poland, Bulgaria, Croatia and Bosnia and Herzegovina on the topic covered in the article. We agreed that the facts, circumstances and assessments presented in this article also apply to the university environment and legal policy regarding the university in these countries. However, a Latvian colleague, who works as a university lecturer at a public university, felt that the critical descriptions and assessments in the article concerning public universities could be generalised, and added with concern his empirically supported thesis that in the Baltic States the policy of attributing greater importance and value to academic work published abroad cannot be overlooked, even if in his opinion the administrative criteria for determining the value of such work are less strict than, for example, in Slovenia or Croatia. Therefore, I decided to take a risk with the thesis reflected in the title of the article: it is not just a critical assessment of Slovenian public universities, it is a feature of the university environment and legal policies that have the most overlaps in post-socialist EU member states (comp. Chankseliani and Silova, 2018; Lemon, 2002; Silova, 2009).

We can rightly be very concerned that this problem will escalate in the short term. In Slovenia and all the other EU member states. With the official start of the coronavirus pandemic in 2020 , the study process has shifted from classrooms and lecture halls to the world wide web. Instead of personal contact between professors and students, communication has taken place via apps like ZOOM and Skype. We are now entering a new

watchdogs" for socially active (in the Aristotelian sense "politically active" citizens, so-called political entities or political animals) representatives of various professions, knowledge and socially active citizens ('activists'). Which is comparable, if not entirely equivalent, to the status of the media, public and private, and particularly journalists. Such status is granted by the Court to all those persons who, through their public work, strive for a contemporary observation of social events, for the investigation, research, analysis and commentary of social events, for their listing in publicly accessible works intended for the general public, sharing the knowledge and ideas with the general public and in the 'public interest'. Above all, all socially active people who, through their public relations, work, comment on, criticize and expose unconstitutional, illegal or corrupt actions of political functionaries, the most influential persons in society or power and decision-making centres, the 'modern, contemporarily elite'. The judicial recognition of such status by the Strasbourg Court for those who do so, and consequently the additional judicial protection of this status before national courts, is an important 'normative' Event (deliberately written with a capital letter), which is much more important than, for example, the annual public announcement of "word of the year." This is a normative institutionalisation (through judicial law-making) of a very important, necessary and indispensable form of informal control in society - at the highest supranational judicial level. Even if, on the other hand, one would rightly expect that the national courts, and especially the Constitutional Courts of the EU member states, to do so much earlier. 
school and study period (October 2020). The measures taken by the government - not only the Slovenian one, as this applies to most EU member states - the study process will occur via the world wide web, at least in the first semester. Parallel to this, there will be a process of even greater bureaucratisation of professors' work: by filling in forms and tables about the hours of their lectures and other work done.

But that is not all. Governments, including the one in Slovenia, are adopting new legal solutions that make vaccination compulsory for all children attending kindergartens and schools, and for all pupils and students. The government predicts ${ }^{28}$ that refusal to vaccinate will bring a ban on the enrolment and admission of children, pupils and students to kindergartens, primary schools, secondary schools and universities. Of course, I cannot delve into this issue in this article. It is too extensive. However, I can say with certainty that all other issues, except for the new virus and post-pandemic measures, have disappeared from the public agenda: from the media, from Parliament, from public discourse.

That is why I am announcing or proposing a thesis: If the state may be said to have hitherto intervened extensively and roughly in the autonomy of the university, from now on that autonomy will be completely abolished. Universities will become a matter of complete control, supervision and 'ownership' of the whole state. All of this may mark the beginning of the end of ideas about social progress, the knowledge society and freedom in a constitutional democracy, as provided for in international law and in the constitutions of European countries. Perhaps a social darkness awaits us, the gloom of the modern Dark Ages. And technological development is clearly something that can shed light on this subject.

\section{Post scriptum}

When I had a discussion with Prof. Mladen Dolar (Teršek, 20I8a), I asked him about his thoughts on "political idiocy", the philosophy on "natural law" and "unwritten laws", "morality" and the general social meaning, the political importance of philosophy. In indirect connection to the academia community and university environment, I set out my translation of one of his answers here:

28 National Assembly of the Republic of Slovenia adopted the Act Amending the Communicable Diseases Act at its session on 29 September 2020 . An initiative to review the constitutionality of this legal regulation has already been submitted to the Constitutional Court of the Republic of Slovenia. It should be noted that the final decision of the European Court for Human Rights in the case Vavricka and Others vs. the Czech Republic has been awaited on for some time, which includes the question of the admissibility of the legal regulation from the constitutional law and international law viewpoints. For more on this, see Teršek (2020). 
"You see, first of all I would say that in order for a democracy to work, in order for a society to work... Hegel saw this problem very, very well... It needs something that Hegel called, and that is a little difficult to translate into other languages - morality, let's say morality. Not moralism or ethics, but morality. Morals and morality. And what does that mean? It means that any business that otherwise relies on laws that are written laws and as such are directly applicable, is applicable, and there is a letter of the law that can be invoked, or no business will ever stand together... What is needed in society is a set of customs and practices based on unwritten laws. For certain common, commonly accepted moral goods that cannot be legislated, they cannot be enforced by law. In other words, there must be some kind of consensus that is very difficult to achieve precisely because it cannot be legislated. A certain definite consensus on what is permissible and what is not permissible, what is appropriate and what is not appropriate.

What is morality? Let's say: Someone gives you gifts, does you a favour, and you say thank you. What does thank you mean? There is no law that says you have to say thank you. It means a minimal acknowledgement of what the other person did to you, what they were not forced to do - and you say thank you. What would happen if you stopped saying thank you? I mean, in a sense... we would not be breaking any law, nothing would happen apparently, but in a sense society would fall apart. That we have certain moral criteria, criteria of morality - how we behave towards each other, what is appropriate and what is not. Criteria that cannot be - that is the point - cannot be clearly defined. You cannot write them down and say: this is it.

And it seems to me that the problem of today's Slovene society is largely the problem of Hegelian morality. This means that certain types of statements, certain types of thinking, certain actions, which should simply be considered obscene, are actually allowed in the political sphere. Not that they should be prohibited by law, because here - let us say the problem of hate speech - it is always difficult to calibrate the right to freedom of expression and hate speech on the other side.

In a way, it is always incomprehensible to me - and this is a question of morality - a question of common consensus, customs and practices. What is permissible, what is appropriate and what is not? And I have the impression that, especially in the last ten years, the standards of public discourse in Slovenia have fallen very sharply. That it is suddenly permissible to say and do things that could not have been done publicly even in the beginning after independence and also in socialist times. And that the consensus criteria for what is decent and obscene are beginning to fall, 160 
which is very difficult to remedy. This cannot be put back by a few decrees. And you see, if you remember Milosevič, Serbia, what first happened in Serbia, before the whole disintegration of Yugoslavia, wars and so on, was a terrible decline in public speech and morality. That is, what is decent to say. And these are things that can be destroyed very quickly. But then it takes decades to rebuild.

And here it seems to me that this is a question of decency, of 'common decency', which in a sense is always the most important political question. Unwritten laws that cannot be included in the political program or in legislation, and the question of stupidity, that something that is obviously stupid is publicly permissible... it seems to me that this too falls into the category of falling criteria of decency, morality and custom. This is what poisons us a little in this country, very poisonous, because it also arouses this general depression that in some general puddle of manure a man can no longer do this, even if he says his opinion, not much will change for him".

\section{References and Sources}

Administrative Court of the Republic of Slovenia Judgment No. IU 2178 / 2009-16.

Avbelj, M. (2019) 》58. člen (avtonomnost univerz in drugih visokih šol)《 (Autonomy of universities and high schools). In Avbelj, M. (ed.). Komentar Ustave Republike Slovenije. Del ı: Človekove pravice in temeljne svoboščine (Commentary on the Constitution of the Republic of Slovenia. Part I: Human rights and fundamental freedoms), pp. 492-500. Nova Gorica: Evropska pravna fakulteta, Nova univerza.

Bauman, Z. (2016) Postmoderna etika (Postmodern ethics). Ljubljana: Znanstvena založba Filozofske fakultete Univerze v Ljubljani.

Benedetič, A. (1999) Poti do univerze (Paths towards university). Ljubljana: Studia Humanitatis.

Bennetot Pruvot, E., and Estermann, T. (eds.) (2017) University Autonomy in Europe III: The Scorecard (2017). European University Association, Brussels (Belgium). Available at: <https://eua.eu/downloads/publications/university\%2oautonomy\%20in\%2oeurope\%20iii\%2othe\%20 scorecard\%202017.pdf> (6.11.2020).

Boelen, C., and Woollard, B. (2009) Social accountability and accreditation: a new frontier for educational institutions. Medical Education 43 (9). Available at: <https://onlinelibrary.wiley.com/doi/full/ıo.IIII /j.1365-2923.2009.03413.x> (free access) 
Breznik, M. (20II) O čem pravzaprav govorimo, ko govorimo o avtonomiji? (What are we actually talking about when we talk about autonomy?). Delo, Sobotna priloga. 19.2.2011.

Burawoy, M. (n.d.) Public Sphere Forum. University of California, Berkeley. publicsphere.ssrc.org. N.D. Available at: <http://publicsphere.ssrc.org/ burawoy-redefining-the-public-university/> (20.7.2020)

Chankseliani, M., and Silova, I. (2018). Reconfiguring Education Purposes, Policies and Practices during Post-socialist Transformations: Setting the stage. In Chankseliani, M. and Silova, I. (eds.). Comparing PostSocialist Transformations purposes, policies, and practices in education, pp. 7-25. Oxford, UK: Symposium Books.

Clark, B. R. (1998) Creating Entrepreneurial Universities: Organizational Pathways of Transformation. International Association of Universities Press/Pergamon - Elsevier Science. New York.

Constitutional Court of the Republic of Slovenia. Decision No.

U-I-22/94. Available in English translation at: <https:// www.us-rs.si/decision/?lang=en\&q=U-I-22\%2F94\&d$\mathrm{f}=\& \mathrm{dt}=\& \mathrm{af}=\& \mathrm{at}=\& \mathrm{vd}=\& \mathrm{vo}=\& \mathrm{vv}=\& \mathrm{vs}=\& \mathrm{ui}=\& \mathrm{va}=\& \mathrm{page}=\mathrm{r} \&$ sor $\mathrm{t}=$ \&order $=\& \mathrm{id}=95242>(2.8 .2020)$

ECtHR (European Court of Human Rights). Final Decision in the case Magyar Helsinki Bizottsag vs. Hungary (2016).

Estermann, T., and Nokkala, T. (eds.) (2009) University autonomy in Europe I: Exploratory study. European University Association, Brussels (Belgium). Available at: < https://eua.eu/downloads/publications/university\%2oautonomy\%2oin\%2oeurope\%201\%20-\%2oexploratory\%2ostudy\%20.pdf> (6.11.2020)

Estermann, T., Nokkala, T., and Steinel, M. (eds.) (20II) University Autonomy in Europe II: The Scorecard. European University Association, Brussels (Belgium). Available at: < https://www.researchgate.net/publication/216508555_University_Autonomy_in_Europe_ II_The_Scorecard> (6.111.2020)

Eurostat Statistics Explained. Youth unemployment. May 25, 2020. Available at: < https://ec.europa.eu/eurostat/statistics-explained/index. php?title $=$ Youth_unemployment\&oldid $=481063>(5.8 .2020)$

Faganel, A., and Trnavčević, A. (2016) Diskurz marketizacije javnega visokošolskega izobraževanja skozi časopisne članke (Discourse of marketing higher public education through newspaper articles). Koper: Založba Univerze na Primorskem. Available at: http://www.hippocampus.si/ISBN/978-96I-6984-45-4.pdf(5.6.2020).

Freitag, M. (2010). Brodolom univerze in drugi eseji iz politične epistemologije (University Shipwreck and Other Essays in Political 
A. TERŠEK • PUBLIC UNIVERSITIES IN POST-SOCIALIST STATES COULD BECOME 'UN-ACADEMIC'...

Epistemology). Ljubljana: Založba Sophia. Galimberti, U. (2oro) Grozljivi gost. Mladi in nihilizem (A horrible guest. Youth and nibilism). Ljubljana: Modrijan.

Gilbert. D. (2013) Spotikanja o sreči (Stumbling over happiness). Ljubljana: Lisac \& Lisac.

Haidt, J. (2013) The Righteous Mind (In Slovenian translation: “Pravičniški um"). Ljubljana: UMco Publishing.

Klemenčič, M., and Zgaga, P. (2015). Slovenia: The Slow Decline of Academic Inbreeding. In Yudkevich M. M., Altbach, P. G. and Rumbley, L. E. (eds.). Academic Inbreeding and Mobility in Higher Education. Palgrave Studies in Global Higher Education (pp. 156-181). London: Palgrave Macmillan.

Klemenčič, M., Flander, A., and Žagar Pečjak, M. (2015) Pogoji akademskega dela v Sloveniji: Ugotovitve študije EUROAC 2013. Ljubljana: Center RS za mobilnost in evropske programe izobraževanja in usposabljanja.

Komljenovič, J. (20II) Privilegij z namenom: avtonomija univerze (Privilege with a purpose: the autonomy of university «). Delo 53(4I), I9 February 201 .

Komljenovič, J. 20ı: University autonomy in the European higher education area: Notes for presentation. In The future of (European) higher education: proceedings. Ljubljana: Centre for Educational Policy Studies, CEPS: Faculty of Education, 201 I.

Lemon, A. (2002) Fieldwork Dilemmas: Anthropologists in Postsocialist States. In H. G. DeSoto, H.G., and Dudwick, N. (eds.). Fieldwork dilemmas. Anthropologists in postsocialist states. Madison: University of Wisconsin Press.

Lesjak, D. (20II) Drzna (visokošolska) Slovenija? (Daring (higher education) Slovenia?). Finance. No. 86/2011. Available at: <https://www.finance. $\mathrm{si} /$ ?cat $=98 \& \mathrm{maxdat}=201 \mathrm{I}-05-06>(27.7 .2020)$

Magna Charta Universitatum. Available at: <http://www.magna-charta. org/pdf/mc_pdf/mc_slovenian.pdf.> (5.6.2020)

Marušič, D. (1997) Kakšna univerza? 2000: Revija za krščanstvo in kulturo (2000: Journal for Christianity and Culture). No. I05, p. 5I.

Močnik, R. (20II) Konec univerze, zmaga visokega šolstva. Bo teorija ostala brez institucionalne podpore? (The end of the university, the victory of higher education. Will theory be left without institutional support?) Available at: <http://www.sociologija.si/wp-content/uploads/20II/os/ Univerza_OS.pdf $>$ (19.7.2020) 
Mowbray, A. (2004) The Development of Positive Obligations Under the European Convention on Human Rights by the European Court of Human Rights. Oxford. Hart Publishing.

Polanec, S. (20II) Kako do boljših diplomantov? (How to get better graduates). Pogledi, No. 6, 9 March 201 I.

Polsky, S., E. (2005) How to Run a University. The Harvard Crimson. 22 February 2005. Available at: <https://www.thecrimson.com/article/2005/2/22/faculty-dismiss-proposed-mediation-committee-professors $/>(20.7 .2020)$

Radonjič, D. (2009) Kriza akademske zavesti (Crisis of Academic Consciousness). Dnevnik. 30.10. 2009.

Silova. I. (2009) Varieties of Educational Transformation: The Post-Socialist States of Central/Southeastern Europe and the Former Soviet Union. In Cowen, R., and Kazamias, A. (eds.). International Handbook of Comparative Education (SIHE), vol. 22 (pp. 295-320). Springer Science+Business Media B.V.

Splichal, S. (2002) Kaj je narobe z univerzo? Kapitalistični bogovi so padli na glavo (What is wrong with the university? The capitalist gods have fallen on their heads). Dnevnik, Objektiv. 30.11.2002

Splichal, S. (2010) The decline of the university as a public institution. Delo, 20.2.2010.

Sruk, V. (1986) Morala in etika - leksikon (Morality and Ethics - Lexicon). Ljubljana: Cankarjeva založba.

Sruk, V. (1995) Leksikon politike (Lexicon of Politics). Maribor: Založba Obzorja.

Šturm, L. (ed.) (2020) Komentar Ustave Republike Slovenije (Commentary on the Constitution of the Republic of Slovenia). Ljubljana: FPDEŠ.

Svetlik, I. (1996) Avtonomija in integracija univerze (Autonomy and integration of the university). In Crnkovič, M. (ed.). Slovenska smer (Slovenian way), pp. II9-I33. Ljubljana: Cankarjeva založba.

Teixeira, P., Jongbloed, B. B., Dill, D. D., and Amaral, A. (eds.) (2004) Markets in Higher Education: Rhetoric or Reality? Dordrecht: Springer.

Teršek, A. (2015) Teorija legitimnosti in sodobno ustavništvo (Theory of Legitimacy and Modern Constitutionalism). Koper: Univerzitetna založba Annales, Univerza na Primorskem., pp. 312-322.

Teršek, A. (2008) Za civilni pogum (For civil courage). Pravna praksa. No. 3/2008, 24.2.2008. 
A. TERŠEK • PUBLIC UNIVERSITIES IN POST-SOCIALIST STATES COULD BECOME 'UN-ACADEMIC'...

Teršek, A. (2017) Universities and knowledge: Bring them back together. Slavonic Pedagogical Studies Journal 6(2), 277-287.

Teršek, A. (2018) O smrti univerze in nemišljenjskih profesurah. (Pogovor s prof. Toncijem Kuzmanićem) (About the death of the university and unthinking professorships. A discussion with Prof. Tonči Kuzmanić). IUS INFO. 25 May 2018. Available at: < https://www.iusinfo.si/medijsko-sredisce/kolumne/221483> (full access)

Teršek, A. (20I8a) Odločilna je nravnost - veljava nenapisanih 'zakonov'. Pogovor s prof. Mladenom Dolarjem (Morality is crucial - the validity of unwritten 'laws'. A discussion with Prof. Mladen Dolar). IUS INFO. I1.5.2018. Available at: < https://www.iusinfo.si/medijsko-sredisce/ kolumne/220432> (full access)

Teršek, A., and Žgur, M. (2010) (Financial) autonomy of the university: Responsibility for freedom and responsible freedom. REVUS. Journal for Constitutional Theory and Philosophy of Law. No. 14/2010. Available at: <https://journals.openedition.org/revus/1349> (2.8.2020)

Teršek, A. (2020) "Compulsory Vaccination and Fundamental Human Rights”, F. Kresal and M. Amon eds. Sustainability and Physiotherapy. III. Scientific Symposium. Visokošolski zavod Fizioterapevtika, Ljubljana, pp. 105-I22.

Türk, D. (2008) The importance of academic freedom today, a speech on the 2oth anniversary Magne Charte Universitatut. Bologna, i8 September 2008. Available at: <http://www.up-rs.si/uprs/uprs.nsf/dokumentiweb/4908CD0236266I8ECI2574CDo031BA9E?OpenDocument.> (20.7.2020)

University Autonomy in Europe. Available at: < https://www.university-autonomy.eu/> (6.11.2020)

Zgaga P. (2018) Autonomy and Accountability in Higher Education, Eastern Europe. In Teixeira, P., and Shin, J. (eds.). Encyclopedia of International Higher Education Systems and Institutions. Dordrecht: Springer Science+Business Media. Available at: < https://link.springer.com/referenceworkentry/10.1007\%2F978-94-017-9553-I_I6I-I> (5.II.2020)

Zgaga. P. (2017) Higher Education Systems and Institutions, Slovenia. In Teixeira, P., and Shin, J. (eds.) Encyclopedia of International Higher Education Systems and Institutions. Dordrecht: Springer Science+Business Media. Available at: <https://link.springer.com/referenceworkentry/I0.1007\%2F978-94-017-9553-I_378-I> (5.1I.2020)

Zupančič, B. M. (1994) Dissenting opinions to the Constitutional Court of the Republic of Slovenia Decisions No. U-I-22/94 and U-I-34/94. 